\title{
Time Resolved Emission of Sidestream Smoke Particles*
}

by

\author{
R. Dittmann, H.-J. Feld, \\ Lehrstubl und Institut für Thermische Strömungsmaschinen, \\ Universität Karlsrube, W-7500 Karlsrube 1, Germany \\ and
}

B.-H. Müller, W. Schneider,

$B \cdot A \cdot T$ Cigarettenfabriken GmbH, W-2000 Hamburg 50, Germany

\section{SUMMARY}

By means of the dispersion quotient method, the aerosol properties of freshly produced sidestream smoke were measured during the puff and subsequent interpuff period. These measurements were made on short time scales and at high aerosol concentrations. Examples are presented, which show the influence of different combustion conditions during the puff (resulting from different degrees of ventilation and different types of tobacco) on the emission of sidestream particles during the interpuff period. The ratio of the volume concentrations of the particles before and during a puff is reduced by ventilation and is nearly unchanged by the variation of the tobacco type.

\section{ZUSAMMENFASSUNG}

Mit der Dispersionsquotientenmethode werden die Nebenrauchpartikel kurz nach ihrer Entstehung bei hohen Konzentrationen und in kurzen Zeitintervallen während des Zuges und der anschließenden Zugpause gemessen. Anhand von Beispielen wird der Einfluß unterschiedlicher Verhältnisse in der Zugphase (die durch unterschiedliche Ventilationsgrade und unterschiedliche Tabaktypen bedingt sind) auf die Emission der Teilchen während der Zugpausenphase gezeigt. Der Quotient der Teilchenvolumenkonzentrationen vor und während eines Zuges wird durch Ventilation verringert, bleibt aber bei einer Variation der Tabaktypen nahezu unverändert.

\footnotetext{
" Received: 18th November 1991 - accepted: 22nd January 1992
}

\section{RESUME}

En utilisant la méthode du quotient de dispersion, on a déterminé les propriétés des particules de la fumée secondaire peu de temps après sa formation, pendant la bouffée et la pause subséquente, les mesures étant effectuées à intervalles de courte durée et à concentration élevée. Les exemples présentés illustrent l'effet de différentes conditions de combustion (selon le taux de ventilation et le type de tabac utilisé) sur l'émission de particules pendant la phase de non aspiration. Il en résulte que le rapport des concentrations volumiques des particules diminue avant et pendant la bouffée du fait de la ventilation, mais qu'il demeure pratiquement inchangé lorsqu'on fait varier le type du tabac.

\section{INTRODUCTION}

Published ratios of the mainstream to sidestream smoke constituent deliveries, produced by a single type of cigarette, vary by several orders of magnitude (1-3). There is also a marked variation in the mainstream/ sidestream delivery ratios of a single smoke constituent among several types of cigarette (4). The ratios are determined by complex physical and chemical processes. Two important influencing factors for the mainstream/ sidestream delivery ratio are the burning velocity and the smoldering velocity of the cigarette. By making some changes in cigarette design, rough estimates can be made of the resulting mainstream/sidestream delivery ratios of some smoke constituents (e. g. particulate matter), if the effects of the changes in cigarette design on the burning 
and smouldering velocities are known.

For a more accurate estimate of the resulting mainstream/ sidestream ratios (and for a better understanding of the underlying mechanisms) more detailed information is required on the relative contributions to the sidestream particulate matter yield during the puff, and during the smoulder period. Moreover, the influence of a puff on the emission into the sidestream during the subsequent smoulder period has to be evaluated. This information may be useful to estimate the potential of different alternative ways to modify the delivery of the sidestream smoke.

For these objectives an experimental device is required to characterize separately the freshly produced sidestream particles that are released during the puff and during the smouldering period. This means that measurements must be made in short time intervals, immediately after the beginning and after the end of a puff.

\section{EXPERIMENTAL}

The application of the dispersion quotient technique to measurements of highly concentrated aerosols during short time intervals is discussed by WITTIG et al. (5). Measurements of cigarette smoke particles in undiluted mainstream by means of this method have been reported previously (6).

The experimental apparatus is shown in Figure 1. The sidestream is drawn through the test area by a fan. The volume flow rate is $150 \mathrm{l} / \mathrm{h}$ during the entire measure-

Figure 1.

Experimental apparatus. ment. A convergent-divergent flow channel provides stationary laminar flow of the smoke through the test area. Pollution of the optical windows is avoided by placing them into external chambers which are rinsed by air from outside the flow channel. Attenuation of the two laser beams of different wavelengths is measured after they have passed through the smoke stream. Hence, the particle diameter, and subsequently the particle concentration, can be calculated with the following equations (6):

$$
\frac{I}{I_{0}}=\mathrm{e}^{-L \cdot N \cdot \pi}{ }_{0}^{\infty} \varphi(r) r^{2} \cdot Q_{e x r} d r
$$

$$
\begin{aligned}
D Q & =\frac{\ln \left(\frac{I}{I_{0}}\right) \lambda_{1}}{\ln \left(\frac{I}{I_{0}}\right) \lambda_{2}} \\
& =\frac{0^{\infty} \varphi(r) \cdot r^{2} \cdot Q_{\text {ext }}\left(r, \lambda_{1}\right) d r}{{ }_{0}^{\infty} \varphi(r) \cdot r^{2} \cdot Q_{e x t}\left(r, \lambda_{2}\right) d r},
\end{aligned}
$$

with

$I / I_{0}=$ intensity ratio of the attenuated and the incident beam,

$L \quad=$ path length of the beam through the particle cloud,

$N \quad=$ particle number concentration,

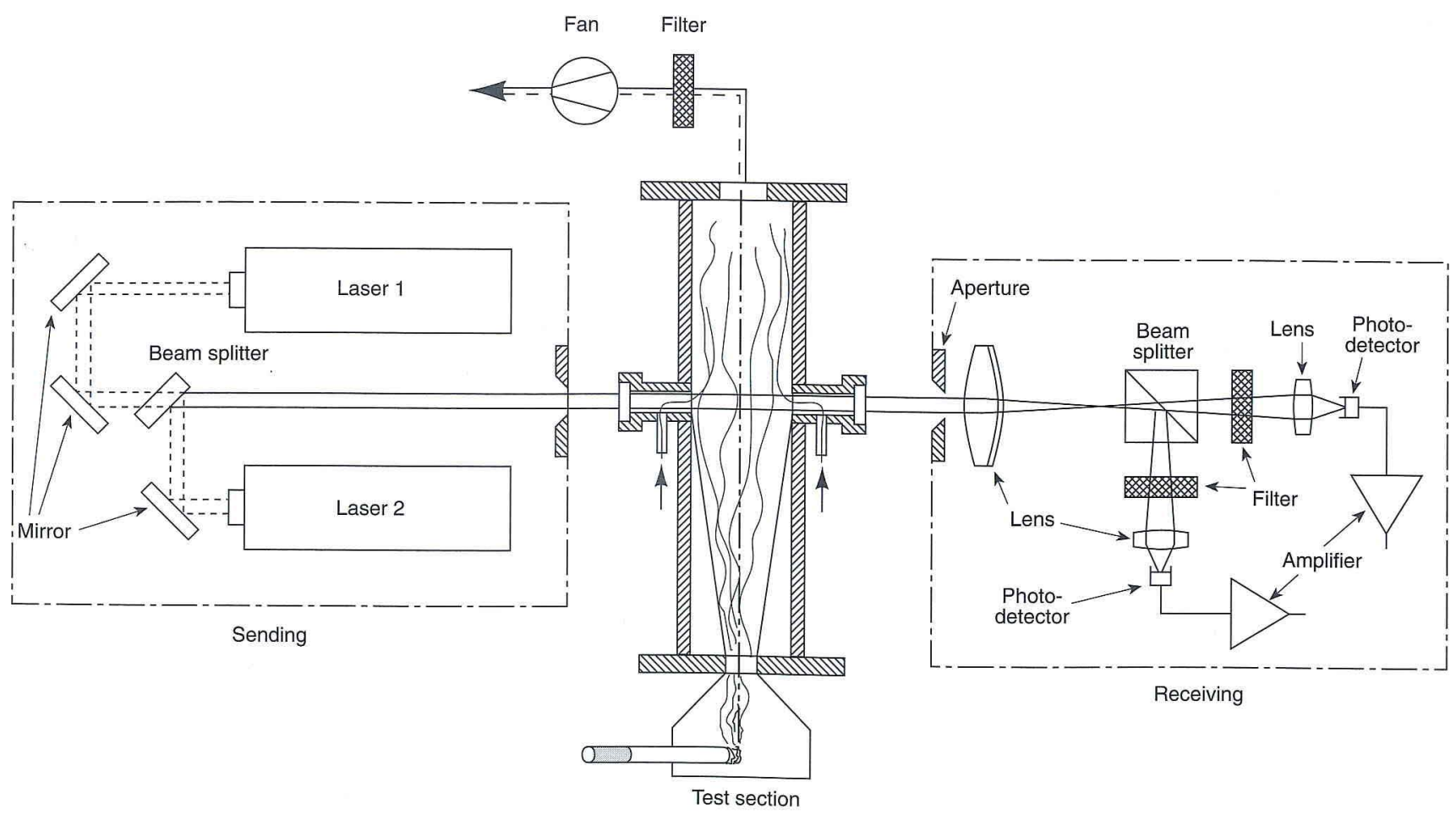


$Q_{\text {ext }}=$ extinction coefficient, given by Lorentz-Mie theory,

$r \quad=$ particle radius,

$\lambda_{1}, \lambda_{2}=$ wavelengths of the laser beams,

$\varphi \quad=$ particle size distribution.

The particle size distribution is assumed to be lognormal with a logarithmic standard deviation $\sigma \mathrm{g}=0.4$. This value corresponds to the average value presented by OKADA et al. (7). It can be shown that the diameter determined by the dispersion quotient technique is approximately the volume mean diameter (8). The complex refractive index is assumed to be $m=1.45-0.00133 \mathrm{i}(9,10)$. The influence of an incorrect or varying value (10) of the real part $n$ of the refractive index is illustrated in Figure 2.

The exact value of the density within the particles is not known. Therefore the volume concentration of the particles is directly applied to give some information on the mass concentration in the sidestream. The volume concentration $v_{p}$ here is calculated by

\section{Figure 2.}

The influence of the value of the refractive index on the determination of the particle diameter;

- $-n=1.40,-n=1.45, \ldots \ldots . n=1.50,--\square=1.60$.

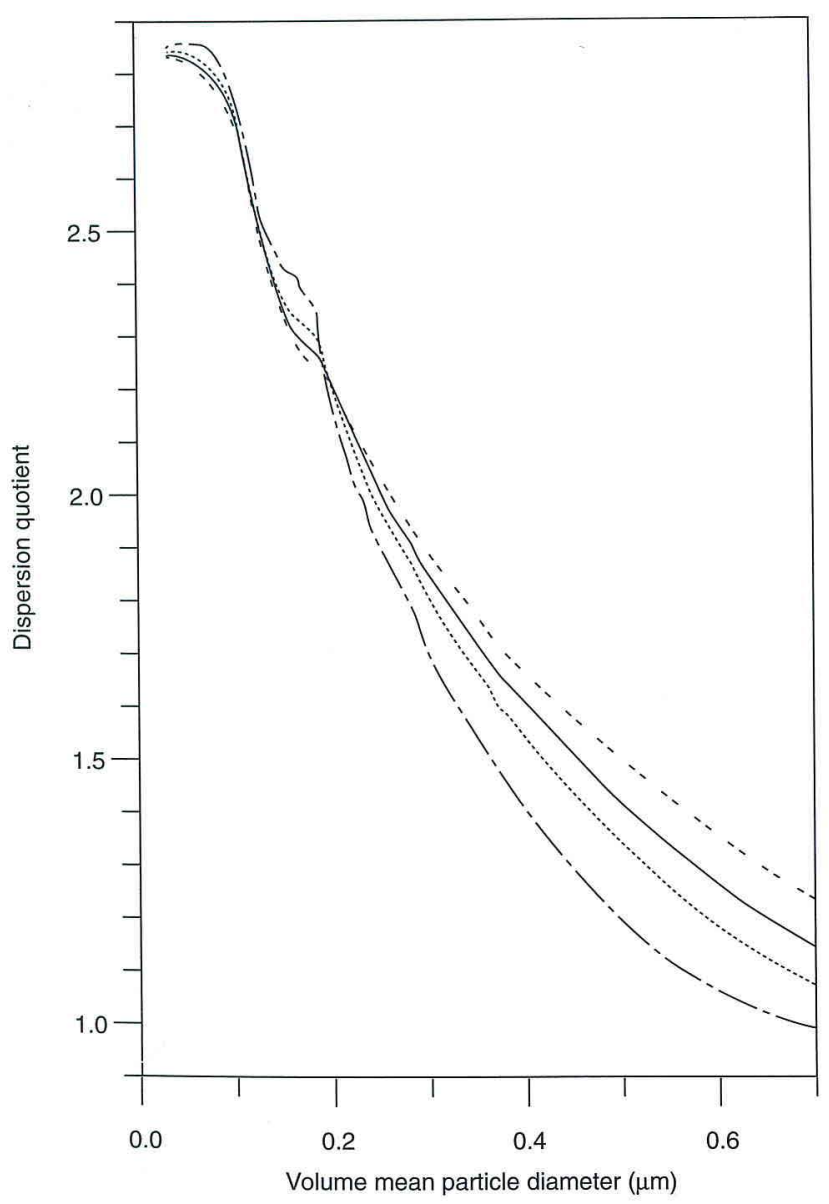

$$
v_{p}=N \cdot 4 \pi / 3 \cdot r_{g}{ }^{3}
$$

where

$\begin{array}{ll}N & =\text { number concentration }\left(\text { particles } / \mathrm{cm}^{3}\right) \\ r_{g} & =\text { volume mean radius. }\end{array}$

\section{SAMPLES}

The cigarettes described in Table 1 were smoked according to standard smoking conditions (CORESTA):

Table 1.

Description of the samples.

\begin{tabular}{|c|c|c|c|c|}
\hline Samples & A & B & C & D \\
\hline \multicolumn{5}{|l|}{ Tobacco rod } \\
\hline - Type & $\begin{array}{l}\text { Flue- } \\
\text { Cured }\end{array}$ & $\begin{array}{l}\text { Flue- } \\
\text { Cured }\end{array}$ & Oriental & Burley \\
\hline - Length (mm) & 63 & 63 & 63 & 63 \\
\hline - Diameter (mm) & 7.95 & 7.94 & 7.92 & 7.94 \\
\hline - Weight (mg) & 850 & 850 & 885 & 700 \\
\hline - Pressure drop (mm W.G.) & 60 & 60 & 62 & 56 \\
\hline $\begin{array}{l}\text { - Permeability of } \\
\text { cigarette paper (C.U.*) }\end{array}$ & 32 & 32 & 31 & 30 \\
\hline Filter & \multirow{2}{*}{\multicolumn{4}{|c|}{ Standard cellulose acetate }} \\
\hline - Type & & & & \\
\hline - Length (mm) & 21 & 21 & 21 & 21 \\
\hline - Pressure drop (mm W. G.) & 50 & 50 & 50 & 50 \\
\hline - Degree of ventilation (\%) & 0 & 60 & 0 & 0 \\
\hline
\end{tabular}

* Coresta unit.

\section{RESULTS AND DISCUSSION}

Apart from the lighting interval, the time dependent behaviour of the volume concentration of sidestream smoke particles from cigarette A follows a typical pattern, as shown in Figure 3. There is a decrease in the volume concentration during the puff, which is followed by a steep increase immediately after the puff. After a typical time interval of about 10 seconds the average concentration level is reached. The volume concentration fluctuates near this value during the rest of the interpuff period. Relatively large fluctuations have to be expected, even if dynamic effects of the sidestream flow are not considered. The time interval of two successive measurements is less than 0.1 seconds, which corresponds to a smouldering length of less than $0.01 \mathrm{~mm}$. Within this scale neither chemical nor physical homogeneity of those properties, which determine the particle formation processes, are determined. In Figures 4 to 6 the number concentration, the volume mean particle diameter and the resulting particle volume concentration (of cigarette A) are presented from 30 seconds before until 30 seconds after the third puff. The variations of the diameter are comparatively small. Thus the time behavior of the volume con- 
centration is mainly determined by the time behaviour of the number concentration.

The measured values of the mean particle diameters measured in this work are larger than the values reported previously $(11,12)$. This is at least partly due to the fact

Figure 3.

Volume concentration of the smoke particles emitted to the sidestream during the smoking of a cigarette according to standard conditions.

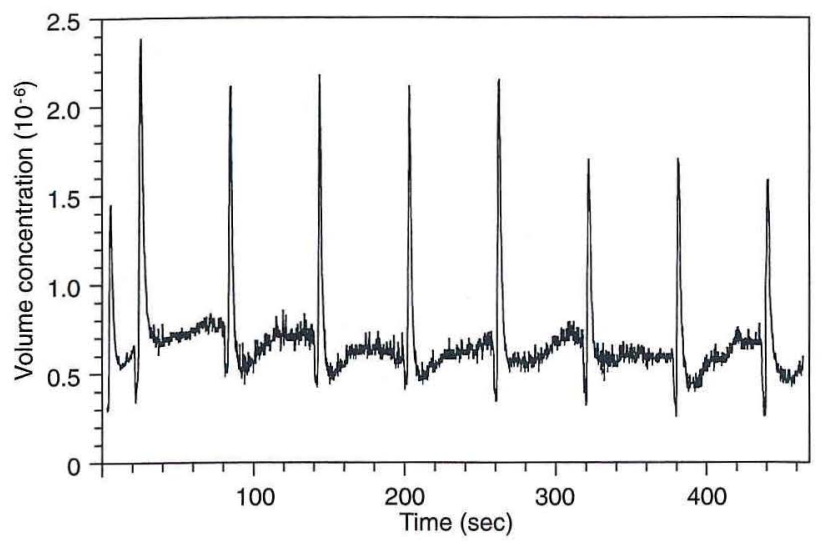

Figure 4.

Number concentration of the sidestream particles before, during and after the third puff.

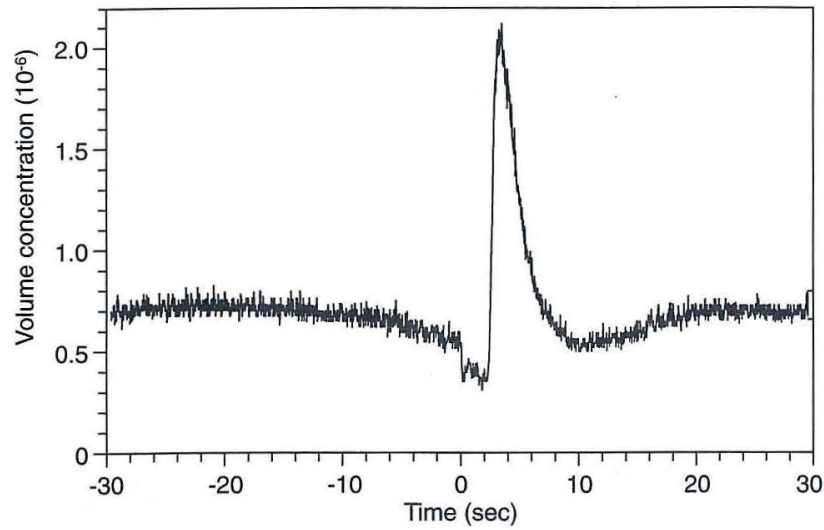

Figure 5.

Volume mean particle diameter of the sidestream particles before, during and after the third puff.

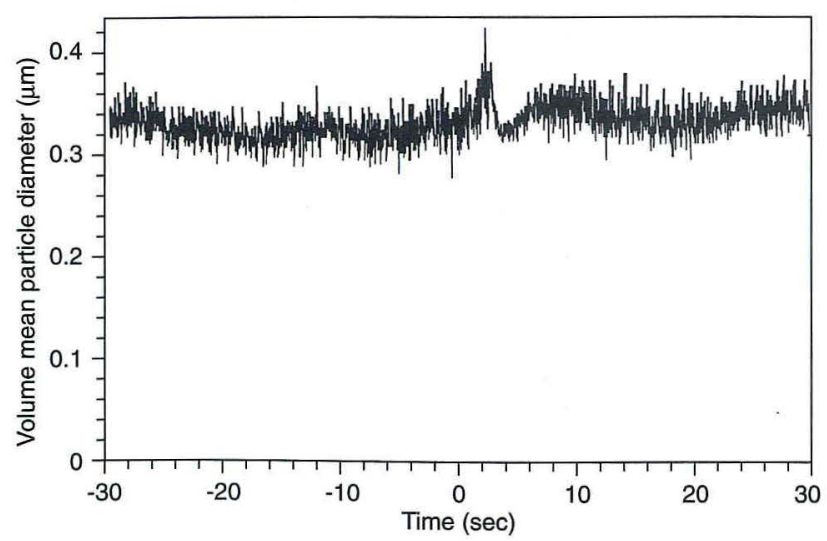

that the concentration of the particles in the present study is larger by several orders of magnitude than those of previous studies, and the saturation ratios of semivolatile constituents in the gas phase of the test area used in this work are distinctly larger than previous values.

Figure 6.

Volume concentration of the sidestream particles before, during and after the third puff.

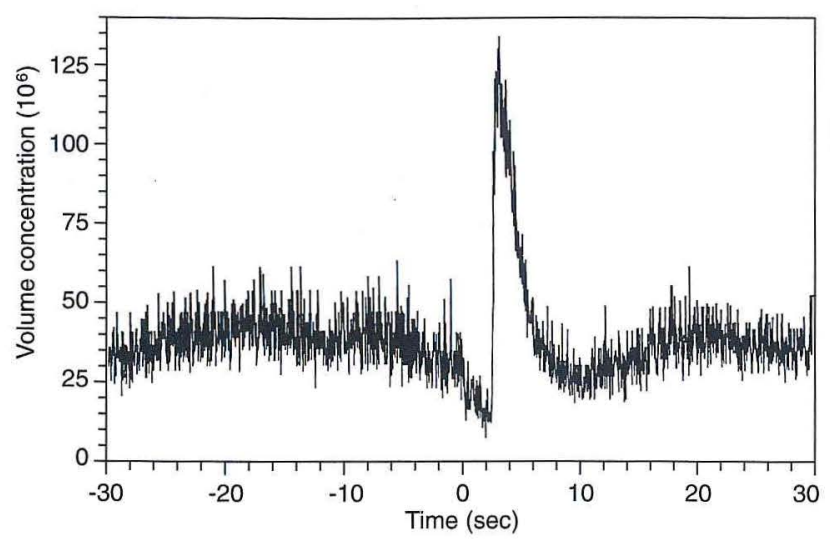

In Table 2 the average values of the number concentration, the volume mean particle diameter and the volume concentration before the puff (averaged over the last 30 seconds of the interpuff period), during the puff (averaged over 2 seconds) and immediately after the puff (averaged over the time interval from 2 to 10 seconds after the puff) are compared:

Table 2.

Ratios of number concentrations, volume mean diameters and volume concentrations before, during and after a puff (sample A).

\begin{tabular}{ll}
\hline Ratio number concentration before/during puff & 1.65 \\
Ratio volume mean diameter before/during puff & 0.98 \\
Ratio volume concentration before/during puff & 1.58 \\
\hline Ratio number concentration during/after puff & 0.43 \\
Ratio volume mean diameter during/after puff & 1.0 \\
Ratio volume concentration during/after puff & 0.45 \\
\hline Ratio number concentration before/after puff & 0.71 \\
Ratio volume mean diameter before/after puff & 0.98 \\
Ratio volume concentration before/after puff & 0.71 \\
\hline
\end{tabular}

The observation that a considerable proportion of the particles are emitted into the sidestream during the puff is compatible with the results obtained by RoBINson et al. (13). They have shown that the amount of the velocity of the convection flow into the sidestream is comparable to the flow velocity into the mainstream. The distinct increase in the emission of the sidestream smoke immediately after the puff has been reported previously (11). This observation demonstrates that the emission of the sidestream smoke during the interpuff period is depen- 
dent on the combustion conditions during the puff. These conditions are essentially determined by all of the features of the cigarette design which influence the air flow through the tobacco rod. An example for these influences of combustion conditions during the puff on the sidestream delivery during the interpuff period can be extracted from the data given by Browne et al. (4): The sidestream delivery of condensate per puff interval decreases with increasing levels of ventilation, and consequently decreasing values of the puff volume at the coal. The results in Table 3 give an example of how the difference of the sidestream emission rates between the puffs and during the puff is changed when the cigarette is ventilated.

Table 3.

Ratios of volume concentrations before and during a puff (samples A-D).

\begin{tabular}{l|c|c|c|c}
\hline \multicolumn{1}{c|}{ Samples } & A & B & C & D \\
\hline Type of tobacco & $\begin{array}{c}\text { Flue- } \\
\text { Cured }\end{array}$ & $\begin{array}{c}\text { Flue- } \\
\text { Cured }\end{array}$ & Oriental & Burley \\
$\begin{array}{l}\text { Degree of } \\
\text { ventilation (\%) }\end{array}$ & 0 & 60 & 0 & 0 \\
$\begin{array}{l}\text { Ratio: } \\
\text { Volume concentration } \\
\text { before/during puff }\end{array}$ & 1.58 & 1.27 & 1.61 & 1.63 \\
\hline
\end{tabular}

One explanation for this phenomenon may be that the differences in the physical and chemical conditions between the puff and the interpuff period (14) are reduced with decreasing mainstream flow volume. The reduction in the sidestream emission may also partly be due to the flow by free convection, which is influenced by the degree of filter ventilation (15). The effects of the three different types of tobacco on the ratio of the volume concentrations before and during a puff seem to be negligible.

\section{REFERENCES}

1. Johnson, W. R., R. W. Hale, J. W. Nedlock, H. J. Grubbs, and D. H. Powell: The distribution of products between mainstream and sidestream smoke; Tob. Sci. 17 (1973) 141-144.

2. Klus, $H$., and $H$. Kuhn: Verteilung verschiedener Tabakrauchbestandteile auf Haupt- und Nebenstromrauch; Beitr. Tabakforsch. Int. 11 (1982) 229-265.

3. Baker, R. R., and C. J. Proctor: The origins and properties of environmental tobacco smoke; Environ. Int. 16 (1990) 231-245.

4. Browne; C. L., C. H. Keith, and R. E. Allen: The effect of filter ventilation on the yield and composition of mainstream and sidestream smokes; Beitr. Tabakforsch. Int. 10 (1980) 81-90.

5. Wittig, S., R. A. Zahoransky, and K. Sakbani: The dispersion quotient technique in sub-micron particlesize analysis; J. Aerosol Sci. 12 (1981) 183-184.
6. Schneider, W., E. Kausch, S. Wittig, and H.-J. Feld: The mean particle size in fresh undiluted cigarette smoke determined by means of the dispersion quotient method; J. Aerosol Sci. 19 (1988) 895-898.

7. Okada, T., and K. Matsunuma: Determination of particle-size distribution and concentration of cigarette smoke by a light scattering method; J. Colloid Interface Sci., 48 (1974) 461-469.

8. Bro, K.: The optical dispersion quotient method for sizing of soot in shock tube induced combustion; Thesis, Purdue University, 1978.

9. Kerker, M., M. J. Sculley, W. A. Farone, and A. J. Kassmann: Optical properties of cigarette smoke aerosols; Appl. Opt. 17 (1978) 3030.

10. McRae, D. D.: The refractive index of individual cigarette smoke droplets; J. Colloid Interface Sci. 87 (1982) 117-123.

11. Ishizu, Y., K. Ohta, and T. Okada: Changes in the particle size and the concentration of cigarette smoke trough the column of a cigarette; J. Aerosol Sci. 9 (1978) 25-29.

12. Ingebrethsen, B. J., and S. B. Sears: Particle evaporation of sidestream tobacco smoke in a stirred tank; J. Colloid Interface Sci. 131 (1989) 526-536.

13. Robinson, D. P.: Aerodynamic characteristics of the plume generated by a burning cigarette; in Proceedings of the International Conference on the Physical and Chemical Processes Occurring in a Burning Cigarette, Winston-Salem, NC, 1987, pp. 115-150.

14. Baker, R. R.: Temperature variation within a cigarette combustion coal during the smoking cycle; High Temp. Sci. 7 (1975) 236-247.

15. Seehofer, F., and W. Schulz: Zur Kenntnis des Glimmstromes von Cigaretten; Beitr. Tabakforsch. 3 (1965) 151-156.

\section{Addresses of authors:}

R. Dittmann and H.-F. Feld,

Lebrstubl und Institut für

Thermische Strömungsmaschinen,

Universität Karlsrube,

W-7500 Karlsrube 1,

Germany.

B.-H. Müller and W. Schneider,

$B \cdot A \cdot T$ Cigarettenfabriken $\mathrm{GmbH}$,

Forscbung und Entwicklung,

Babrenfelder Chaussee 139,

W-2000 Hamburg 50,

Germany. 